UDC 332.3:349.415

\title{
PARTICULAR ISSUES OF ANALYSIS OF COLLISIONS OF THE CURRENT LAND LEGISLATION
}

Dorosh Y., Doctor of Economics, Professor, Corresponding Member of NAAS, Institute of Land Use of NAAS of Ukraine, e-mail:landukrainenaas@gmail.com Dorosh O., Doctor of Economics, Professor National University of Life and Environmental Sciences of Ukraine e-mail:dorosh_o@nubip.edu.ua

Avramchuk B., Candidate of Economic Sciences, Institute of Land Use of NAAS of Ukraine, e-mail:avramchuk.bogdan@gmail.com

Barvinsky A., Candidate of Agricultural Sciences, Institute of Land Use of NAAS of Ukraine, e-mail:barv@ukr.net

\section{Demchuk $V$.}

Institute of Land Use of NAAS of Ukraine, e-mail:demchuknaan@ukr.net

The article analyzes the main legal conflicts that arisen as a result of the adoption of changes to the land legislation of Ukraine during 2020-2021.

It was found out that the transfer of land for use requires a permit for the development of technical documentation on land management to establish (restore) the boundaries of land in kind (on the ground). At the same time, there is another conflict - the specified technical documentation performs the same function as the land management project for the allocation of land for use.

As a result of the analysis of amendments to the Law of Ukraine "On Land Management", it is established that the wording of the text of the article in terms of the basis of work has two interpretations, the first of which concerns privately owned 
land, and the second - state and municipal land in use .

In addition, it was found that in the latest versions of regulations, the terms "owner" and "owner (manager)" meet next to each other, which allows us to state that the authors of the regulation aimed to separate the disposal of private land from one on the one hand and state and communal - on the other.

Key words: legislative acts, land plots, land management, division (association) of land plots, privatization of land plots.

Problen statement. Legislation of Ukraine in the field of land relations and land management is constantly in a state of change, additions and improvements. However, in the period from 2020 to 2021, the Verkhovna Rada of Ukraine, the Cabinet of Ministers of Ukraine and the ministries adopted a number of regulations that directly or indirectly amend the country's land legislation.

At the same time, given that most regulations are adopted by various public authorities, it is assumed that there is some inconsistency between the new amendments to the legislation. Additionally, in some cases such inconsistency creates regulatory collisions and gives freedom in the interpretation of legislation in the field of land relations.

Analysis and understanding of the nature and consequences of such collisions is one of the goals of this study. The next step after highlighting the main legislative inconsistencies is to provide proposals for their elimination by optimizing regulations.

Analysis of recent research and publications. Problems of legislative support of land relations in Ukraine are devoted to the works of A. Barvinsky [5], D. Dobryak [4], Y. Dorosh [5-6], O. Dorosh [7-8], V. Drugak [10], L. Novakovsky [9], I. Novakovskaya [5], M. Stetsyuk [5], A. Tretyak [10] and others, however, amendments to the legislation in recent years require additional study and justification.

The purpose of the article is to analyze and highlight the main legal conflicts that have arisen as a result of the adoption of changes to the land legislation of 
Ukraine during 2020-2021.

Presentation of the main research material. Analyzing the current regulations, it is necessary to divide them into those that directly affect land legislation and those whose main purpose is not to regulate land relations, but whose rules significantly change these relations.

Thus, the regulations of direct effect on land legislation include:

- Law of Ukraine "On Amendments to Certain Legislative Acts of Ukraine Concerning Land Use Planning” [1] of June 17, 2020 № 711-IX (entered into force on July 24, 2021);

- Law of Ukraine "On Amendments to Certain Legislative Acts of Ukraine Concerning the Improvement of the Management and Deregulation System in the Sphere of Land Relations” [2] of April 28, 2021 № 1423-IX (entered into force on May 27, 2021);

- $\quad$ Resolution of the Cabinet of Ministers of Ukraine "On Amendments to Certain Acts of the Cabinet of Ministers of Ukraine" [1] of July 28, 2021 № 821 (entered into force on August 11, 2021);

- $\quad$ Resolution of the Cabinet of Ministers of Ukraine "On Amendments and Repeal of Certain Resolutions of the Cabinet of Ministers of Ukraine" [1] of February 12, 2020 № 134 (entered into force on 06.06.2020).

The normative legal acts that have a significant impact on land legislation, but the main purpose of which is not to regulate land relations include the following:

- Law of Ukraine "On Amendments to Certain Legislative Acts of Ukraine on Simplification of the Procedure for Connection to Electric Networks" [1] of 15.07.2021 № 1657-IX (entered into force on 20.08.2021);

- Resolution of the Cabinet of Ministers of Ukraine "Some issues of ensuring the functioning of the Unified State Electronic System in the field of construction" [1] of June 23, 2021 № 681 (entered into force on 02.07.2021);

- Resolution of the Cabinet of Ministers of Ukraine "On determining the format of electronic documents of a comprehensive plan of spatial development of the territorial community, master plan of the settlement, detailed plan of the territory" 
[1] of June 9, 2021 № 632 (entered into force 24.07.2021).

As a result of the analysis of the Law of Ukraine "On Amendments to Certain Legislative Acts of Ukraine on Improving the Management System and Deregulation in the Sphere of Land Relations" [2] of 28.04.2021 № 1423-IX as one that currently has the most significant impact on the sphere of land relations revealed changes related to the development of one of the most common land management documentation - "technical land management documentation for the establishment (restoration) of the boundaries of land plots" [3].

Thus, in the new version of Article 118 of the Land Code [1] it is established that when a citizen privatizes a land plot within the norms of free privatization "technical documentation on land management to establish (restore) the boundaries of the land plots" [3] without granting permission for its development (Table 1).

Table 1

\section{Regulation of the development of technical documentation on land} management for the establishment (restoration) of the boundaries of land plots

Land Code of Ukraine

\section{A citizen interested in the privatization of a land} plot within the norms of free privatization, which is in his use, including the land plot on which a residential building, outbuildings, structures located in his ownership are located, submits an application to the relevant executive body. government or local government $[\ldots]$.

The application is accompanied by technical documentation on land management developed in accordance with the Law of Ukraine "On Land Management" to establish (restore) the boundaries of the land in kind (on the ground), which is ordered by a citizen without permission to develop it.

(Land Code item 1 of article 118)
Law of Ukraine "On Land

Management"
In case of transfer of ownership and use of land on the basis of technical documentation on land management to establish (restore) the boundaries of land in kind (on the ground) by decision of the Verkhovna Rada of the Autonomous Republic of Crimea, the Council of Ministers of the Autonomous Republic of Crimea, executive body technical documentation is developed on the basis of a permit issued by the relevant authority.

(Law "On Land Management" paragraph 4 of Article 55) 
At the same time, Article 55 of the Law of Ukraine "On Land Management" [3] as amended by the Law № 1423-IX regulates the need to obtain permission to develop the above land management documentation for the transfer of ownership (ie, privatization) and use of land.

That is, the transfer of land for use still requires "permission to develop technical documentation on land management to establish (restore) the boundaries of land in kind (on the ground)" [3]. In this case, there is another conflict - such technical documentation performs the same function as the land management project for the allocation of land for use.

The next controversial issue, which will be widely used in the field of land relations, is the regulation of the basis for the development of "technical documentation on land management for the division (consolisation) of land" [3]. Article 56 of the Law of Ukraine "On Land Management" provides that "technical documentation on land management for the division and consolidation of land is developed by the decision of landowners with the consent of mortgagees, land users" [3].

Thus two ways of interpretation of the above-stated norm are seen:

1) the decision on division (consolidation) of land plots is made exclusively by the owner of land plots with the consent mortgagee or user, as shown in Figure 1-a;

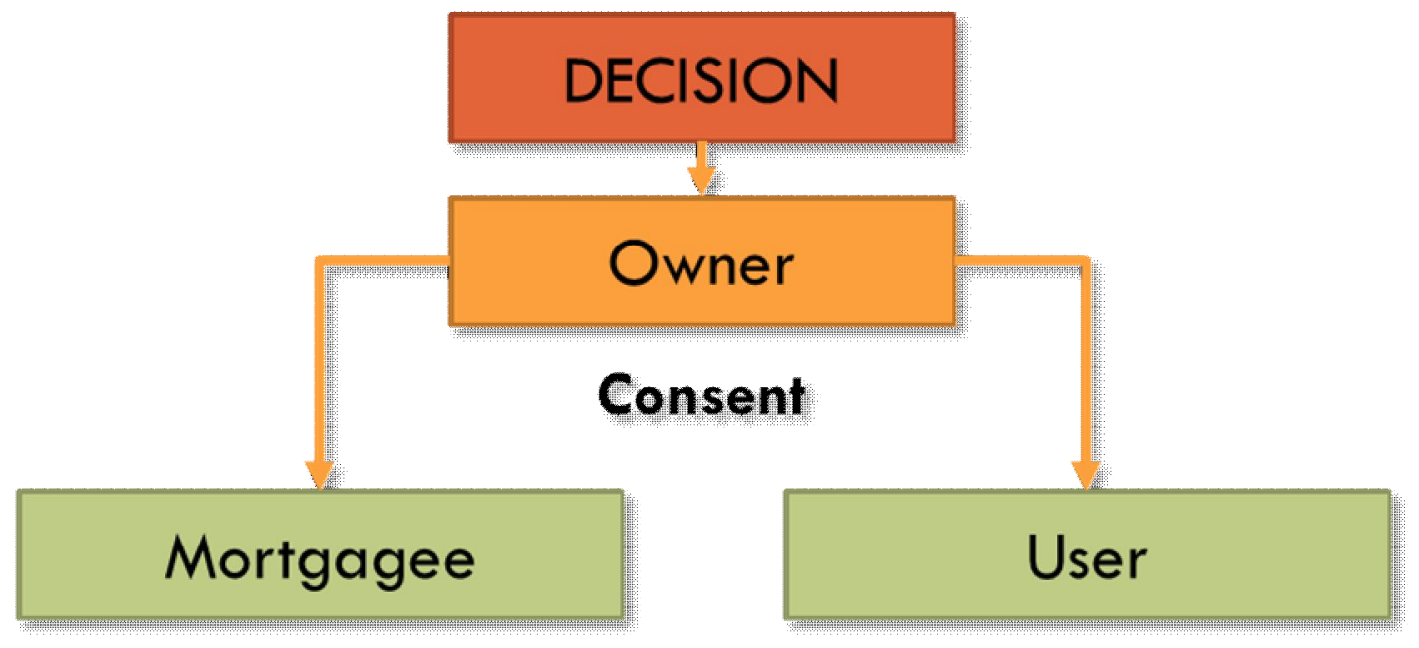

Fig. 1-a. The basis for the development of technical documentation on land management for the division (consolidation) of land. The first way. 
2) the decision on the division (consolisation) of land is made either by the owner of the land with the consent of the mortgagee or the user, as shown in Figure $1-b$

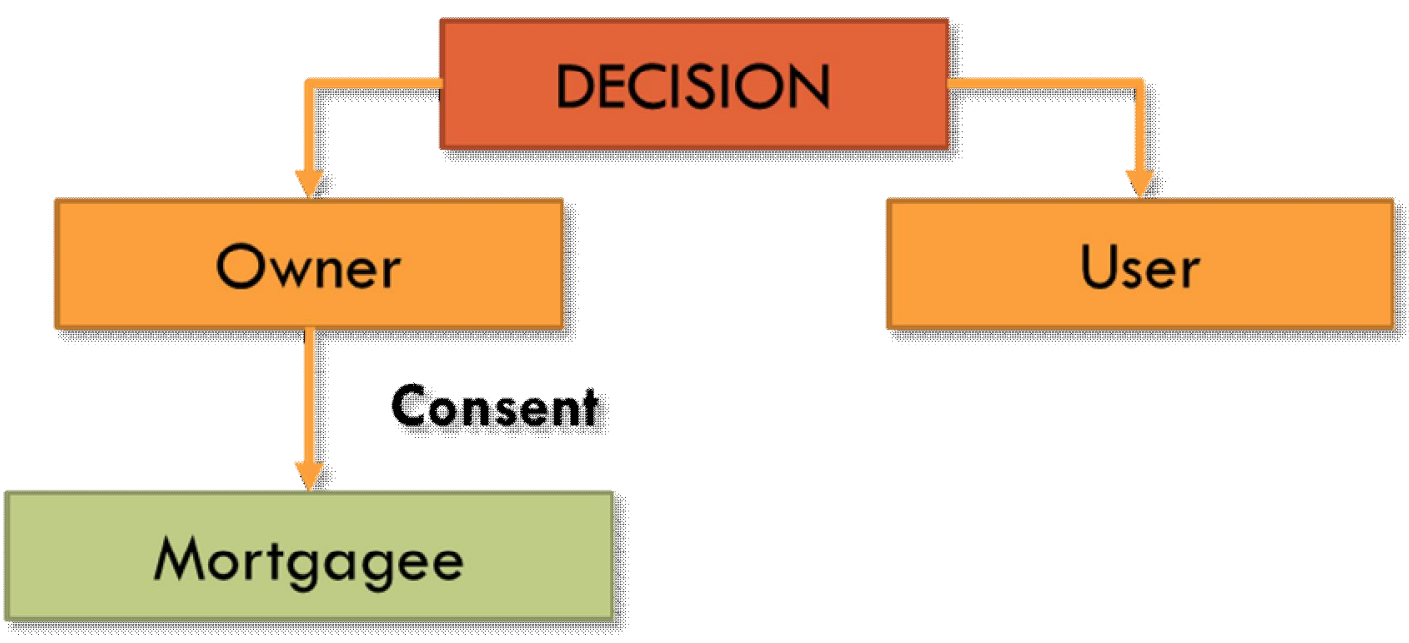

Fig. 1-b. The basis for the development of technical documentation on land management for the division (consolisation) of land. The other way.

It should be emphasized that the first way is considered logical and legal, but the authors of the Law № 1423-IX in the text of the normative act provides for the concept of "owner" and "owner (manager)". That is, if the land plot of state or communal property is in the use of a natural or legal person, it can be considered that such land plot has an owner (manager) and a user.

Thus, analyzing the general logic of the Law № 1423-IX and Article 56 of the Law of Ukraine "On Land Management", we can conclude that the first route concerns privately owned land, and the second - state and municipal land plots that are in use [3].

During the analysis of the Law of Ukraine "On Amendments to Certain Legislative Acts of Ukraine on Improving the Management System and Deregulation in the Sphere of Land Relations" [2] of 28.04.2021 № 1423-IX the terms "owner" and "owner (manager)" occur side by side with each other, which allows to state that the authors of the normative act were intended to divide the disposal of land plots of private property on the one hand and state and communal - on the other. 
Analyzing Article 186 of the Land Code of Ukraine as amended, we can see that the difference in the concepts of "owner" and "owner (manager)" is legal in nature and is not an error or omission in the legislation. For example, in paragraph 5 of this article, both concepts are used depending on the regulation of approval of a land management documentation.

Conclusions. Thus, analyzing the general logic of the Law № 1423-IX, it was found that the transfer of land for use requires "permission to develop technical documentation on land management to establish (restore) the boundaries of land plots" [3]. At the same time, there is another conflict - the specified technical documentation performs the same function as the land management project for the allocation of land for use.

As a result of the analysis of amendments to Article 56 of the Law of Ukraine "On Land Management", we can conclude that the wording of the text of the article in terms of the basis of work has two ways of interpretation, the first of which concerns privately owned land, and the second - state and municipal land, which are in use.

In addition, it was found that in the latest versions of regulations, the terms "owner" and "owner (manager)" meet next to each other, which allows us to state that the authors of the regulation aimed to separate the disposal of privately owned land from one on the one hand and state and municipal - on the other.

\section{References}

1. The Verkhovna Rada of Ukraine (2001), The Law of Ukraine "Land Code of Ukraine". Available at: http://zakon4.rada.gov.ua/laws/show/2768-14.

2. The Verkhovna Rada of Ukraine (2021), The Law of Ukraine "On Amendments to Certain Legislative Acts of Ukraine Concerning the Improvement of the Management and Deregulation System in the Sphere of Land Relations". Available at: https://zakon. rada.gov.ua/laws/show/1423-20\#top

3. The Verkhovna Rada of Ukraine (2003), The Law of Ukraine "On land management". Available at: http://zakon2.rada.gov.ua/laws/show/858-15.

4. Dobryak D., Martyn A. (2009) Napriamy vdoskonalennia normatyvno- 
pravovoi bazy rehuliuvannia zemelnykh vidnosyn [Directions for improving the regulatory framework for land relations]. Land Management and Cadastre. № 4. P. 5 -10 .

5. Dorosh Y. et al. (2021) Zakonodavche zabezpechennia rehuliuvannia v haluzi vykorystannia ta okhorony zemel [Legislative provision of regulation in the field of land use and protection]. Land management, cadastre and land monitoring. № 2. P. 14-25. DOI: http://dx.doi.org/10.31548/zemleustriy2021.02.02

6. Dorosh Y. (2011) Okremi aspekty vdoskonalennia zemelnoi polityky v Ukraini shchodo administruvannia zemelnykh vidnosyn ta systemy zemlekorystuvannia [Some aspects of improving land policy in Ukraine regarding the administration of land relations and land use system]. Effective Economy. № 9.

7. Dorosh O. (2015) Metodychni pidkhody do vyhotovlennia tekhnichnoi dokumentatsii iz zemleustroiu shchodo podilu ta obiednannia zemelnykh dilianok [Methodical approaches to the preparation of technical documentation on land management for the division and consolidation of land]. Economist. № 6, Volume 344. P. 40 - 41.

8. Dorosh O.S. (2017) Kontsept rozpodilu funktsii upravlinnia zemlekorystuvanniam $\mathrm{v}$ konteksti rozvytku terytorialnykh hromad [The concept of distribution of land management functions in the context of territorial community development]. Zbalansovane pryrodokorystuvannia, № 3, 97 - 107.

9. Novakovsky L. (2009) Shliakhy udoskonalennia zakonodavchoho zabezpechennia rozvytku zemelnykh vidnosyn $\mathrm{v}$ Ukraini [Ways to improve the legislative support for the development of land relations in Ukraine]. Economics of AIC. № 3. P. 21 - 23.

10. Tretyak A. et. al (2010) Zakonodavcho-normatyvni problemy ekolohichnykh vidnosyn prav vlasnosti ta prav korystuvannia zemleiu v Ukraini [Legislative and normative problems of ecological relations of property rights and land use rights in Ukraine]. Ecological sciences: scientific and practical journal. № 6, Volume 344. P. 82. 
Дорош Й.М., Дорош О.С., Барвінський А.В., Аврамчук Б.О., Демчук B.O.

ДЕЯКІ ПИТАННЯ АНАЛІЗУ КОЛІЗЙ ЧИННОГО ЗЕМЕЛЬНОГО ЗАКОНОДАВСТВА

У статті проаналізовано основні правові колізії, щзо виникли у результаті прийняття змін до земельного законодавства Украӥни протягом 2020-2021 років.

3'ясовано, що передача земельної ділянки у користування передбачає наявність дозволу на розробку технічної документаиії із землеустрою щцодо встановлення (відновлення) меж земельних ділянок в натурі (на місиевості). Водночас при изьому виникає інша колізія - вказана технічна документація виконує таку ж функиію як і проект землеустрою щзодо відведення земельних ділянок у користування.

У результаті аналізу змін до Закону України «Про землеустрій», мовстановлено, щчо формулювання тексту статті в частині підстави виконання робіт має два шляхи трактування, перший з яких стосується земельних ділянок приватної власності, а другий - державних та комунальних земельних ділянок, які перебувають у користуванні.

Крім того, виявлено, щуо в останніх редакиіях нормативно-правових актів поняття «власник» та «власник (розпорядник)» зустрічаються поруч один з одним, щуо дає змогу констатувати, щчо автори нормативного акту мали на меті розділити розпорядження земельними ділянками приватної власності 3 одного боку та державними і комунальними - з іншого.

Ключові слова: законодавчі акти, земельні ділянки, землеустрій, поділ (об'єднання) земельних ділянок, приватизаиія земельних ділянок.

$* * *$

Дорош Й.М., Дорош О.С., Барвинский А.В., Аврамчук Б.О., Демчук В.О. НЕКОТОРЫЕ ВОПРОСЫ АНАЛИЗА КОЛЛИЗИЙ ДЕЙСТВУЮЩЕГО ЗЕМЕЛЬНОГО ЗАКОНОДАТЕЛЬСТВА 
В статье проанализированы основные правовые коллизии, возникиие в результате принятия изменений в земельное законодательство Украинь в течение 2020-2021 годов.

Выяснено, что передача земельного участка в пользование предполагает наличие разрешения на разработку технической документациии по землеустройству относительно установления (восстановления) границ земельных участков в натуре (на местности). Вместе с тем при этом возникает другая коллизия - указанная техническая документация выполняет такую же функцию, как и проект землеустройства по отводу земельньх участков в пользование.

В результате анализа изменений в Закон Украины «О землеустройстве», мовстановлено, что фрормулировка текста статьи в части основания выполнения работ имеет два пути трактовки, первый из которых касается земельных участков частной собственности, а второй - государственных $и$ коммунальных земельных участков, находящихся в пользовании.

Кроме того, выявлено, что в последних редакцииях нормативно-правовых актов понятие «владелец»» и «владелеи (распорядитель)» встречаются рядом друг с другом, что позволяет констатировать, что авторы нормативного акта имели целью разделить распоряжение земельными участками частной собственности с одной стороны и государственныли и коммунальными - $с$ другой.

Ключевые слова: законодательные акты, земельные участки, землеустройство, разделение (объединение) земельных участков, приватизация земельных участков. 